Статья

\title{
Женские имена в названиях улиц тувинских городов как проблема сохранения социальной памяти этноса
}

\author{
Наталья Л. Пушкарева \\ Институт этнологии и антропологии РАН, Российская Федерация, \\ Александр В. Жидченко \\ Университет Канзаса, США
}
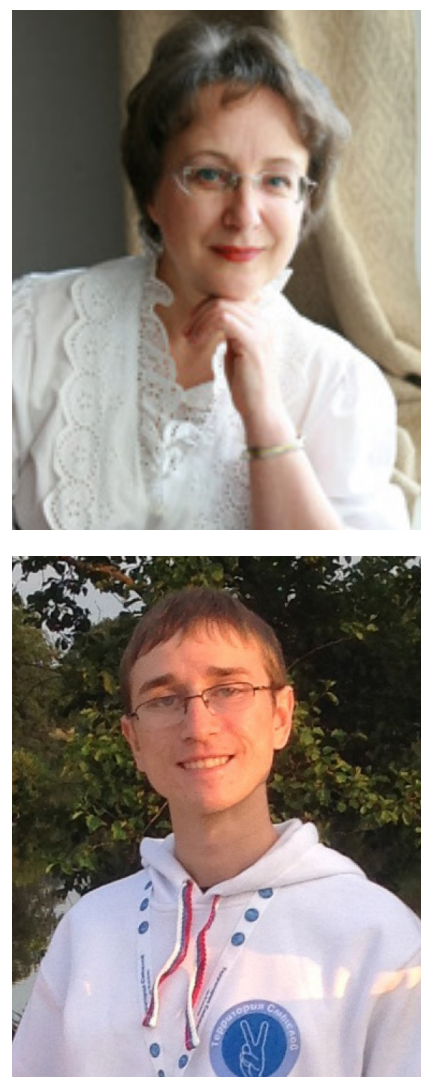

Статья впервые в российской историографии поднимает тему гендерного дисбаланса в наименованиях улии городских поселений Республики Тыва. Анализ проведен на основе изучения стрит-нейминга в городах Кызыл, Ак-Довурак, Шагонар, Чадан, Туран и поселке городского типа Каа-Хем, а также в ряде сел республики. Всего в ходе исследования среди 1325 улии городских поселений Тувы было выявлено 15 улии, названных в честь женщин. Это составляет около 1 процента. Для сравнения, в Москве, из 3127 улиц «женские имена» носят 40, что составляет примерно 1,2 процента.

Авторы анализируют факт обилия мужских имен в стрит-нейминге, сранивают это топонимическое явление с картиной наименования улиц в других городах РФ и зарубежных странах, объясняя гендерно-предвзятые основания нейминга неравным распределением власти между полами в советской и постсоветской истории. Размышляя о создании мемориального ландшафта на постсоветском пространстве, они находят причины сохранения дисбаланса в упущениях градостроительного законодательства (не требующего его соблюдения), в сложившихся гендерных стереотипах национальной культуры и традиционного (патриархального) гендерного контракта.

Тем самым авторы обращают внимание на проблему дисбаланса в городской и сельской топонимике, на недостаточное признание женского вклада в историко-культурное наследие Тувы.

Ключевые слова: стрит-нейминг; этноурбанизм; женская история; город; городская культура; историко-культурное наследие; топонимика; социальная память; Тува; тувинцы; тувинские имена; Кызыл

Финансирование

Статья подготовлена в рамках гранта, предоставленного Министерством науки и высшего образования РФ № 075-15-2020-910.

Для цитирования:

Пушкарева Н. Л., Жидченко А. В. Женские имена в названиях улиц тувинских городов как проблема сохранения социальной памяти этноса // Новые исследования Тувы. 2021, № 1. C. 188-201. DOI: https://www.doi. org/10.25178/nit.2021.1.10

Пушкарева Наталья Львовна - доктор исторических наук, профессор, заведующая центром гендерных исследований Института этнологии и антропологии РАН. Адрес: 119333, Россия, г. Москва, Ленинский пр-т, д. 32-А. Тел.: +7 (495) 938-00-19. Эл. адрес: pushkarev@mail.ru

Жидченко Александр Владимирович - PhD (in History), приглашенный ученый Департамента истории Университета Канзаса (США). Адрес: 1450 Jayhawk Blvd, Lawrence, KS 66045, USA. Тел.: +7 (926) 980-19-52. Эл. адрес: zhidchenko220689@yandex.ru

PUSHKAREVA, Natalia Lvovna, Doctor of History, Professor, Head of the Center for Gender Studies, Institute of Ethnology and Anthropology, Russian Academy of Sciences. Postal address: 32a Leninsky Prospekt, 119333 Moscow, Russian Federation. Tel.: +7 (495) 938-00-19. Email: pushkarev@mail.ru ORCID ID: 0000-0001-6295-3331

ZHIDCHENKO, Alexander Vladimirovich, PhD in History, Visiting Scholar, Department of History, Kansas University. Postal address: 1450 Jayhawk Blvd, Lawrence, KS 66045, USA. Tel.: +7 (926) 980-19-52. Email: zhidchenko220689@yandex. $\mathrm{ru}$ 


\title{
Streets named after females in Tuva as a case of preserving the social memory of an ethnicity
}

Article

\author{
Natalia L. Pushkareva \\ Institute of Anthropology and Ethnography, RAS, Russian Federation, \\ Aleksandr V. Zhidchenko \\ The University of Kansas, USA
}

For the first time in Russian historiography, the article raises the issue of gender imbalance in the names of streets in the Republic of Tuva. The article is is based on the study of street naming in the cities of Kyzyl, Ak-Dovurak, Shagonar, Chadan, Turan, and urban-type settlement Kaa-Khem, as well as a number of rural localities. Among the 1325 streets of Tuvan urban settlements only 15 have been discovered as named after women, which is approximately 1\% of the total. To compare, there are 40 streets with "female names" in Moscow among 3127 streets - approximately $1.2 \%$.

The authors analyze the abundance of male names in street naming, and compare this toponymical phenomenon with the picture in other cities of the Russian Federation and foreign countries, explaining the gender-biased causes of naming by the unequal distribution of power between the sexes in Soviet and post-Soviet history. Examining the set-up of a memorial landscape in the post-Soviet space, the authors find reasons for why the imbalance persists, in the lack of town planning legislation (which does not require compliance with it), in the prevailing gender stereotypes of the ethnic culture and the traditional (patriarchal) gender contract.

The authors thus draw attention to the problem of the imbalance in urban and rural toponymy, and of insufficient recognition of women's contribution to the historical and cultural heritage of Tuva.

Keywords: street naming; ethnic urbanism; women's history; city; city culture; historical and cultural heritage; toponymy; social memory; Tuva; Tuvans; Tuvan names; Kyzyl

\section{Financing}

The article was prepared in the framework of a research grant funded by the Ministry of Science and Higher Education of the Russian Federation (grant ID: 075-15-2020-910).

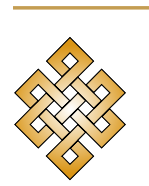

For citation:

Pushkareva N. L. and Zhidchenko A. V. Streets named after females in Tuva as a case of preserving the social memory of an ethnicity. New Research of Tuva, 2021, no. 1, pp. 188-201. DOI: https://www.doi.org/10.25178/nit.2021.1.10

\section{Введение}

На протяжении последнего столетия - от создания 14 августа 1921 г. независимой Республики Танну-Тува (Тувинской Народной Республики) и до современности - в историю этого государственного образования, исторически сложившегося как географический центр Азии, свой вклад вносили не только мужчины (деятели управления и науки, генералы и золотопромышленники, писатели и поэты), но и женщины, дававшие жизнь и воспитывавшие будущих героев страны, хранителей ее духовных богатств (Забелина, 1977а).

Однако написание женской истории Республики Тыва - задача, еще только поставленная и до конца не решенная (Забелина $\left.1977 b^{1}\right)$, ждущая своего «исследователя, талантливое перо которого напишет» ее «живыми красками любви к женскому полу и Отечеству» (Карамзин, 1803: 294).

Задача эта тем более актуальна, поскольку у кочевых народов положение женщин было особенным. В частности, «...утверждение о приниженном положении женщины в дореволюционном тувинском обществе нельзя считать однозначным и бесспорным...» (Субботин, 2016: 118). Тувинские женщины могли разносторонне проявлять себя и в семье (как матери и воспитательницы), и вне ее (Забелина 1977а; Доржу, 1993; Вайнштейн, 1994; Анжиганова, Тюльберова, 2019). Признанием современного социального потенциала женской части населения Тувы являются многочисленные проявления волонтерской и предпринимательской активности современных тувинок, в том числе и регистрация в 2002 г. Тувинского регионального отделения общероссийской общественно-государственной ор-

\footnotetext{
${ }^{1}$ См. также: Женщины Советской Тувы : сборник статей. Кызыл: ТНИИЯЛИ, 1988. 96 с.
} 
ганизации «Союз женщин России» - «Союза женщин Республики Тыва» (сменившего действующую с 1998 г. другую женскую организацию - Национальную лигу женщин Республики Тыва) (Анайбан, 2005; Анжиганова, Ак-Лама, 2016).

Однако и до начала нынешнего, XXI-го века, который многими современными социологами оценивается как «век женщин», то есть как столетие значимости гендерного фактора в социальных процессах, история тувинской земли сохранила немало имен выдающихся женщин. Это Хертек Амырбитовна Анчимаа - государственная и политическая деятельница, возглавившая в 1938 г. Отдел по работе среди женщин при ЦК Тувинской народной рабочей партии; Татьяна Шогжапаевна Камова, в 1930-е гг. бывшая первым женщиной-послом республики в Монголии и ставшая после министром здравоохранения; Монгуш Чанмаевна Часкым, вложившая немало сил в организацию помощи фронту в годы Великой отечественной войны и Вера Чульдумовна Байлак, тувинская доброволец, ушедшая на фронт в годы Великой Отечественной войны, обладательница множества орденов и медалей; активистка женского движения послевоенного времени Зоя Папагаевна Аракчаа, более 10 лет возглавлявшая республиканский женсовет, Тамара Чаш-ооловна Норбу, более 20 лет руководившая областным Советом профсоюзов и мн. др. Можно назвать также Кара-Кыс Намзатовну Мунзук, Народную артистку России и Республики Тыва, Раису Ажыевну Аракчаа, первую женщину-камнереза в Республике Тыва, заслуженную художницу Тувинской АССР и лауреата Государственной премии им. И. Е. Репина и многих, многих других... Достойных имен много. Но многие ли из них оказались запечатленными в топонимике республики?

В общемировой практике названия улиц начали появляться вместе с возникновением больших поселений и воплощая социально-политический порядок повседневной жизни. Этот своеобразный «мемориальный ландшафт», позволяя изучать связи между увековечиванием памяти в названии улицы и гражданской идентичностью, есть бесхитростное отражение распределения власти, в том числе и власти между полами (Azaryahu, 1996). Оно веками предполагало главенствующую роль мужчин и символическое присвоение ими топонимического пространства. Процесс стрит-нейминга (наречения улиц именами) неосознанно складывался как андроцентричный, подразумевающий механизмы исключения для женщин, во всех без исключения странах мира (Haldar, 2013). Отметим, однако, что достаточно было возникнуть, например, в XVIII в. знаменитому «российскому матриархату» (73 года этого века империей управляли женщины), как на карте России появились Екатеринодар, Екатеринослав, Екатеринополь, Елизаветгоф, Анненгоф, станица Елизаветинская, улицы и проспекты, названные именами правительниц или их дочек (Никитин, 2020). Но наступил XIX век - и число российских улиц, поселений, городков, носящих женские имена, не увеличилось, а уменьшилось: император Павел I запретил женщинам занимать трон, и до Великой русской революции 1917-1922 гг. страна управлялась мужчинами. Поэтому на всем протяжении этого исторического отрезка распространение получали лишь топонимы в сельских поселениях, образованные от женских имен (Акулино, Аннино, Варварщина, Василисина, Ганково, Екатеринки, Лукеркино, Машкино, Окулино, Софьино, Ульянино и т. п.). Число их, однако, оказалось крайне невелико (менее 5\%) - в сравнении, скажем, с французской топонимикой: среди названий улиц городков и поселений во Франции XIX в. существовало, по подсчетам исследователей, более 150 топонимов, сконструированных от 80 женских имен (Жиленкова, 2012: 5; Никитин, 2020: 81).

К моменту же основания на территории Тувы города Белоцарска в 1914 г. (ставшего в будущем столицей республики - городом Кызылом) в соседней Российской империи повсеместно продолжали встречаться топонимы, связанные с женскими именами, но процент их в общем процессе стрит-нейминга оставался малозаметным. Однако социально-демографические процессы в тувинском обществе (характерные также и для России в целом) свидетельствуют о том, что именно женщины - главные хранители социальной памяти и преемственности поколений, в том числе и потому, что женской половине населения удалось с меньшими потерями пройти через кризис постперестроечного периода. Мужское же население сокращалось на протяжении и советского периода, и в 1990-е гг. Эти социально-демографические сдвиги сопровождались эрозией традиционных гендерных ролей, сменой уклада, «великим упадком мужчин» (Степанофф, 2009: 134-137).

Данная преамбула в историю наречения улиц именами в Российской империи в целом, и в земле тувинской в частности, необходима для обоснования тезиса: стрит-нейминг - это воплощенный инструмент, используемый при социальном конструировании гендера в городских пространствах. Неравное распределение между полами количества топонимов практически во всех городах мира (баланс абсолютно везде смещен в пользу мужчин, скажем, в Риме 45,7\% улиц города названы в честь 
мужчин, 3,5\% - в честь женщин) ${ }^{1}$ заставляет актуализировать гендерно-чувствительный подход к теме уличной топонимии и социальной памяти в разных городах Европы и Азии и на основе экспертных мнений настаивать на соблюдении гендерного баланса.

Проведя изучение женской социальной памяти в рамках коллективного проекта РФФИ 19-09-00191, мы обнаружили, что наше исследование топонимики городов Тувы оказалось на стыке истории повседневности, новой локальной истории, исторической урбанистики, применяющей гендерно-чувствительные методы работы с эмпирическим материалом. Оно носит сравнительно-исторический характер, поскольку ставит задачей исследовать топонимический ланшафт отдельной республики в сравнении с городами мира и регионами Российской Федерации, главным образом - с Москвой, поскольку именно столица в наибольшей степени исторически задает идеологический тон всей российской топонимике.

Проблемы антропологии города (и в связи с этим названий улиц) в связи с темой сохранности исторической памяти представлены в огромном числе работ российских социологов, антропологов, этноурбанистов, но особенно преуспели историки азиатской (сибирской) части РФ (Баранова, 2011; Полюшкевич, Попова, 2018; Преловская, Пулявская, 2015). В междисциплинарном поиске о проблемах города пишут специалисты по исторической экологии (Историческая экология ..., 2003; Горонова, 2005), досадно мало внимания уделяя гендерным аспектам проблемы. Поэтому мы ставим задачей анализ текущего состояния сохранения исторической памяти в тувинской столице и иных городах, поселках городского типа (ПГТ) и крупных селах Республики Тыва, особое внимание уделяя закреплению в социокультурном пространстве памяти о женщинах тувинской земли и России в целом.

Проникновение в российское историописание феминистской теории и концептов политики гендерной инклюзии предполагает проблематизацию описанного являния («забывания» женщин), заставляя проанализировать, как постоянно воспроизводимый гендерный разрыв влияет на женское социальное самосознание. Такого рода исследование способно придать теоретизированию практическую ориентированность, объяснив, какие эффективные изменения могут потенциально предолеть неравенство на символическом уровне - через изменение баланса в названиях городских улиц.

\section{«Женское» топонимическое пространство Тувы}

Очевидно, что часть топонимического пространства любого города обезличена (это названия улиц, поименованные в связи географическими пунктами - река, гора, местность и т. д.). Необезличенное топонимическое пространство 5 городов Республики Тыва (республиканского значения Кызыл и Ак-Довурак, а также Шагонар, Туран, Чадан, с учетом поселка городского типа - Каа-Хем) формирует историческую память об известных и значимых тувинских деятелях культуры, старейшинах (Д. Б. Танзын-оол, М. М. Самбуу, С. Х. Сат и др.), народных героях, ученых, исторических и общественно-политических деятелях. Эти имена часто повторяются в вышеперечисленных городах, начавших формироваться неполный век, а то и полвека тому назад, встречаясь на десятках улиц, более 90\% которых имеют «мужские имена».

Улицы в Республике Тыва, названные женскими именами, представлены не в историческом центре каждого локуса, а как бы особняком, вне компактной жилой застройки (это бросается в глаза, например, при анализе топонимики Кызыла и прилегающего к нему поселка городского типа КааХем, где расположены улицы Веры Кучун, Агнии Барто и Светланы Савицкой).

Вопрос расположения улиц не так прост, как доказали исследования топонимики других городов, и постоянно находится в в спектре интереса специалистов по теории городской культуры: чем ближе к центру, тем более значима персона (Рыженко, 2010); гендерный аспект темы тут тем более важен - в данном случае он обозначает (не)признание женского вклада в культурную историю этноса (Пушкарева, 2019).

Статистический анализ городских (и в качестве примера некоторых сельских) поселений отражен в таблице № 1. Стоит отметить, что в двух городах республики (Туране и Шагонаре) вовсе отсутствуют улицы, названные в честь женщин или содержащие какую-либо «женскую» тему.

${ }^{1}$ Poon L. Mapping the Sexism of City Street Names. In a study of seven world metros, only a little more than a quarter of the streets were named for women [Электронный ресурс] // Bloomberg CityLab. 2015. URL: https://www. bloomberg.com/news/articles/2015-11-04/mapping-the-sexism-of-street-names-in-major-cities (дата обращения: 10.01.2021). 
Таблица 1. Улицы, названные в честь женщин в населенных пунктах Республики Тыва (по данным на январь 2021 г.) Table 1. Streets named after females in the Republic of Tuva, as of January 2021.

\begin{tabular}{|c|c|c|c|}
\hline $\begin{array}{c}\text { Названия населенных } \\
\text { пунктов, в которых } \\
\text { найдены улицы } \\
\text { с «женскими именами» }\end{array}$ & $\begin{array}{l}\text { Общее } \\
\text { число } \\
\text { улиц }\end{array}$ & $\begin{array}{c}\text { Улицы, названия которых } \\
\text { имеют отношение к женской } \\
\text { социальной памяти }\end{array}$ & $\begin{array}{l}\% \text { от } \\
\text { общего } \\
\text { числа }\end{array}$ \\
\hline \multicolumn{4}{|c|}{ Городские поселения (города и поселок городского типа) } \\
\hline Кызыл & 919 & $\begin{array}{l}\text { Улица Галины Доваадор } \\
\text { Улица Светланы Козловой } \\
\text { Улица Терешковой } \\
\text { Переулок } 8 \text { Марта } \\
\text { Улица Анчимаа-Тока } \\
\text { Улица Кускелдей Тулуш } \\
\text { Улица Маадыр Ие } \\
\text { Улица Виктории } \\
\text { Улица Энзана Пала }\end{array}$ & 0,87 \\
\hline Ак-Довурак & 55 & Улица Идегел (Надежды) & 0,55 \\
\hline Каа-Хем & 137 & $\begin{array}{l}\text { Улица Агнии Барто } \\
\text { Улица Веры Кучун } \\
\text { Улица Светланы Савицкой }\end{array}$ & 2,1 \\
\hline Чадан & 80 & $\begin{array}{l}\text { Улица Нади Рушевой } \\
\text { Улица Сарыглар Часкал }\end{array}$ & 2,5 \\
\hline Шагонар & 77 & - & - \\
\hline Туран & 57 & - & - \\
\hline Bсего: & 1325 & 15 & 1 \\
\hline \multicolumn{4}{|c|}{ 2. Некоторые сельские поселения } \\
\hline Бай-Таг & 51 & Улица Иргит Багбуужап & 1,9 \\
\hline Тээли & 40 & $\begin{array}{l}\text { Улица Дарии Куулар } \\
\text { Улица Уруле Кандан }\end{array}$ & 5 \\
\hline Кызыл-Мажалык & 44 & $\begin{array}{l}\text { Переулок Зои Тырышпаевны } \\
\text { Улица Зои Тырышпаевны }\end{array}$ & 4,5 \\
\hline Баян-Кол & 19 & Ховалыг Бичен & 5,2 \\
\hline Бажын-Алаак & 14 & Амаа Монгуш & 7,1 \\
\hline Эрзин & 90 & - & - \\
\hline
\end{tabular}




\section{Как возник этот дисбаланс?}

Возможно, одной из причин была стихийность процесса урбанизации степного простанства, наслоение разных исторических эпох и имен деятелей тувинской истории и культуры, в которых ведущее положение было за мужчинами (улицы Кечил-Оола, Оюна Курседи, Салчака Тока и др.). Другой причиной могла быть поздняя урбанизация, в ходе которой историческая память фиксировала события, скорее, общероссийского масштаба (улицы Ленина, Гагарина, Красных Партизан, Фрунзе, Колхозная и пр.). Можно предположить и влияние традиционных культурных норм тибетского буддизма как главной религии тувинцев: конфессия не была гендерно-нейтральной (особенно век назад, когда в Туве не было женских монастырей и женщинам не имели доступа даже к буддийскому образованию (собственно единственному - до 1921 года)) и считала (как и другие основные мировые религии) роль женщин второстепенной.

Историческая память, поддерживаемая в том числе посредством городской топонимики, закрепляла знаковые имена в историко-культурном наследии Тувы таким образом, что даже фронтальный просмотр всех карт городов Республики Тыва и всех списков улиц этих городов (используя картографический материал и справочные издания в качестве источников), позволил выделить лишь полтора десятка «женских» улиц! «Язык - инструмент власти, с помощью которого люди преследуют свои интересы» (П. Бурдье); отсутствие до начала 1960-х гг. на територии современной республики улиц, названных женскими именами, - важный показатель равнодушного отношения к женскому вкладу в тувинскую историю: названия улиц отражают историю города и то, что он ценит в прошлом ${ }^{1}$.

Однако вместе с хрущевской оттепелью отношение к ценности такого вклада переменилось. Вместе с появлением массы «советских» названий у улиц (Рабочая, Крестьянская, Комсомольская, Молодежная, Новая и т. д.) в городах и поселках у улиц появились первые «женкие названия».

Столица Республики Тыва (см. рис. 1) обзавелась улицей первой советской женщины-космонавта B. Н. Терешковой. Это был общий топонимческий ответ на выигранное СССР невидимое соревнование с США в области космонавтики: на современных картах РФ сейчас, по данным Яндекс-карт, 324 улицы Терешковой (Никитин, 2020: 57). Улица Терешковой в Кызыле оказалась в центре частной застройки в прибрежной зоне Енисея недалеко от городского центра и по значимости положения ничуть не уступала местоположению улиц Гагарина и Титова. Двадцать лет спустя в поселке городского типа КааХем появилась улица, названная именем второй российской космонавтки - Светланы Савицкой педагога и общественной деятельницы, кандидата технических наук, полковника военно-воздушных сил СССР.

В то же второе послевоенное десятилетие в Кызыле появилась и ул. 8 Марта - символ признания законодательно закрепленного равенства женщин с мужчинами в СССР (позже, в годы стагнации и в постсоветский период улицы уже таких названий не получали). Во множестве советских городов улицы с такими именами подчеркивали не значимость сохранения женской социальной памяти (и потому так мало число улиц, названных в честь Н. К. Крупской, И. Ф. Арманд, А. М. Коллонтай, которые были лидерами делегатского движения в начале великого большевистского эксперимента), а значимость государственной воли и власти в деле «решения женского вопроса в СССР».

Женские имена в названиях улиц Тувы неслучайно появились на картах двух крупных городов именно в 1960-е гг.: к тому времени относят и рождение особой темы в тувинской художественной литературе - темы женской судьбы (подчас пересказанной авторами-мужчинами) ${ }^{2}$. Для всего позднего периода социализма характерно большее дистанцирование от местной истории и использование в стрит-нейминге общих имен, отражающих политическую повестку дня, прославляющих значимых политических деятелей общегосударственного российского масштаба (А. Макаренко, Ф. Дзержинского и др.). Во все времена и во всех странах в периоды географической экспансии местные имена ровно так же заменялись или дополнялись именами, которые прославляли победу там человека, страны, идеологии (Rusu, 2020). Политики повсюду закрепляют названиями улиц свою повестку дня, свои приоритеты в коллективном бессознательном (Azaryahu, 1996: 311-330).

На излете советской эпохи одна из улиц Каа-Хем получила имя советской детской поэтессы, писательницы и киносценаристки Агнии Барто. Исторических связей между тувинским народом и детской

\footnotetext{
${ }^{1}$ Meier, A. Mapping the Gender Imbalance in City Street Names // Hyperallergic. 2015, November 6. URL: https:// hyperallergic.com/251819/mapping-the-gender-imbalance-in-city-street-names/ (дата обращения: 10.01.2021).

${ }^{2}$ Кенин-Лопсан М. Б. Судьба женщины: роман / пер. В. Малюгин. Кызыл: Тувинское книжное изд-во, 1973.256 с.
} 


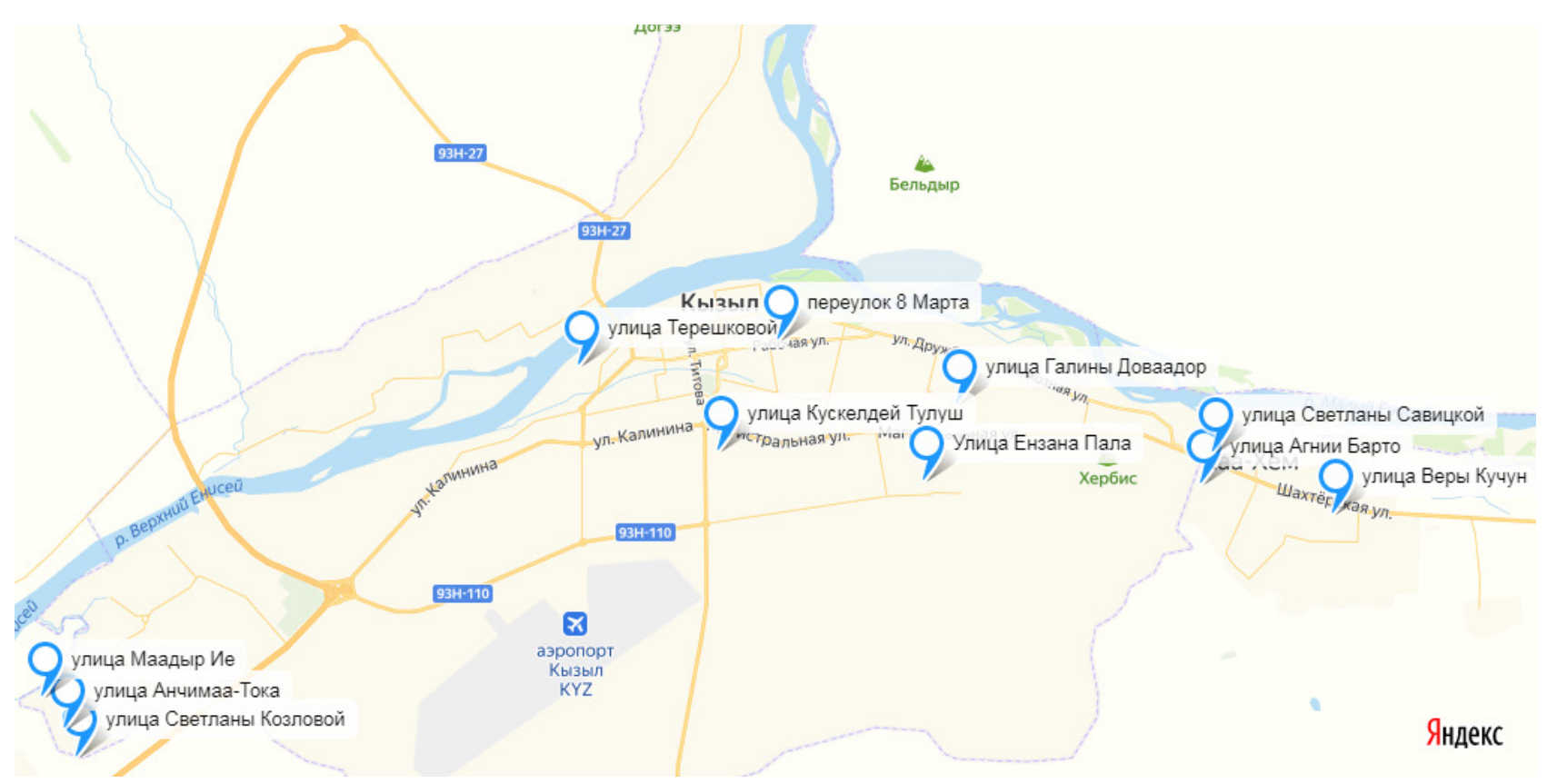

Рис. 1. План г. Кызыла с указанием расположения улиц, названных в честь женщин. Составлен авторами с помощью сервиса Яндекс-карты https://yandex.ru/maps/ Fig.1. Map of the city of Kyzyl with streets named after women highlighted. Made by the authors with the use of Yandex.Maps service https://yandex.ru/maps/

писательницей выявить не удалось, однако несомненно: русские и тувинские дети равно росли на ее произведениях, продолжают расти и современные. В этой части города нет ни детских библиотек (они могли бы установить социокультурную связь с топонимом в городском пространстве), ни педучилища со смежным функционалом, но огромное внимание к педагогическому наследию тувинского народ, масса исследований на эту тему (Вайнштейн, 1961; Мунзук, 1990; Волков, Салчак, Шаалы, 2009; Сундуй, 2009 и др.), подчеркивают понимание значимости именно этой личности для эдукологии ${ }^{1}$ республики. Для общероссийской топонимической традиции улицы, названные в честь Агнии Барто не редкость они есть, например, в Москве, Мурманске, Ижевске и других городах.

Весьма показательно и важно именно для женской социальной памяти Республики Тыва существование улицы Уруле Кандан (1918-1975) - матери-героини, родившей 10 детей и бывшей чабаном колхоза «Победа» Тайгинского района Тувинской АО (за что получила звезду Героя Социалистического труда).Это прекрасное свидетельство памяти о тяжелом труде и непростой жизни выдающейся тувинки, не дожившей даже до 60-летия. Случайно ли, что улица ее имени оказалась не в городе, а только в Тээли - крупном селе (где всего 40 улиц, из которых лишь две - Дарии Куулар и Уруле Кандан - носят женские имена)? Стоит отметить, что увековечивание памяти о Матерях-Героинях можно назвать общесоветской и как преемственность общероссийской традиции - во многих крупных и средних городах есть соответствующие памятники (как символически обезличенные, так и посвященные конкретным местным женщинам, отдавшим сыновей - Героев - фронту). В их честь называли и улицы. Особенность тувинской топонимики в том, что сегодня в городском пространстве Кызыла есть улица Маадыр ие (переводится как «Мать-героиня»). При этом в других российских городах улицы с таким названием, обощающим социальную память о всех матерях-героинях, найдены не были (также, как и отсутствуют в крупных российских городах улицы, названные именами выдающихся матерей-героинь: П. Секиркиной, Е. Степановой, А. Алексахиной и др.).

Позднесоветский период в истории Тувы - время пристального внимания к памяти о Великой Отечественной войне. И не случайно, что из 16 женских имен на улицах городов (городских поселений) Республики Тыва 6 улиц - это улицы героинь, прославивших себя на этой этой войне. Не входившая до 1944 г. в состав СССР тувинская земля дала огромному Советскому Союзу немало защитников, в том

${ }^{1}$ Эдукология - наука о взаимодействиях живых организмов между собой и с их средой обитания. 
числе 10 тувинских героинь. Их именами в разных селах и городах республики названы улицы (Дыртыкоол, 2020). В их числе улица Дарии Куулар в селе Тээли, Иргит Багбуужап в селе Бая-даг, Амаа Монгуш на карте села Бажына-Алаака, Ховалыг Бичен в селе Баян-Кол, Сарыглар Часкал в городе Чадане и Сынаа Кыргыс (Галины Тонмитовны Доваадор) в столичном Кызыле и в селе Булун-Бажы Эрзинского района. Все они заявили о добровольном решении сражаться с фашистами, были призваны 1 сентбяря 1943 г. и в ходе обучения в г. Коврове Ивановской области освоили русский язык, а затем показали свое ратное мастерство на фронтах Великой Отечественной, были награждены орденами и медалями ${ }^{1}$.

Сынаа Кыргыс (Галина Томитовна Доваадор) (1923-2005) писала с фронта: «Жизнь мчится своим чередом, и у нас всякое бывает. Немец сидит за бетоном, за полями мин и колючей проволокой. Нам гнать его надо, и мы гоним его!» ${ }^{2}$ Сама Г. Т. Доваадор стала после войны чемпионкой-наездницей республики ${ }^{3}$, и не случайно названная ее именем улица в социокультурном пространстве Кызыла находится рядом с Конным клубом.

Другая тувинка, память о героизме которой запечатлена в имени одной из улицы города Чадан Сарыглар Часкал, известна куда меньше. Как показала краеведческая работа одного из школьников города Салгала Дулуша, лишь 60\% живущих на этой улице жителей (опрос проводился в 2016 г.) знали историю своей улицы и связывали ее имя с историей тувинских добровольцев ${ }^{4}$. Очевидно, нет никаких доказательств того, что прославление женского дела посредством топонимии каким-либо образом влияет на феномен эмансипации женщин: названия улиц присутствуют в коллективном бессознательном; память об их происхождении со временем теряется (Azaryahu, 2011). Такая проблема возникает, например, при попытке выяснить, кем же была некая Зоя Тырышпаевна - не только улица, но еще и переулок ее имени имеются в селе Кызыл-Мажлык.

Сложность топонимических конструкций в населенных пунктах Тувы проявляется, например, в том, что память об известной в республике участнице Великой Отечественной войны Вере Байлак закреплена лишь в одной из улиц с. Хайыракан Дзун-Хемчикского кожууна. Вместе с тем, несмотря на общереспубликанскую значимость этого имени в тувинском историко-культурном наследии, названной в ее честь улицы в столице - городе Кызыле - нет.

В целом, стоит отметить, что в других городах России более распространена традиция сохранения в городской топонимике памяти не только о местных женщинах - Героях Великой Отечественной войны (например, ул. Валентины Бархатовой в Омске, ул. Елены Колесовой в Ярославле, ул. Клавдии Фомичевой в Москве и др.), но и о женщинах, внесших вклад в Победу в общесоветском масштабе, но не имеющих отношения к этому городу (улицы, площади, бульвары, скверы, названные именами Полины Осипенко, Марины Расковой, Зои Космодемьянской, Лизы Чайкиной в десятках городов бывшего СССР). Однако, отсутствие улиц, названных в честь известных женщин - Героев Великой Отечественной войны, можно объяснить небольшой численностью населения города Кызыла и Республики Тува (стоит предположить, что если бы численность населения Кызыла была сравнима с тем же Новосибирском, то и здесь бы появились улицы с соответствующими именами).

\section{Имена начала XXI века}

Конец XX - начало XXI в. отмечены в топонимике городов Республики Тыва появлением нескольких улиц, названных женскими именами. На окраине столицы, в локусе новой массовой жилой застройки в конце 1990-х гг. возникла улица Светланы Козловой, олицетворившей культурно-историческую близость русского и тувинского народа. В 1950-е гг. молодая российская журналистка отправилась в

\footnotetext{
${ }^{1}$ Их подвиг бессмертен. История тувинских санитарок [Электронный ресурс] // Официальный сайт ГБУЗ РТ Ресбольница №1. 09.05.2020: http://ресбольница.рф/их-подвиг-бессмертен-история-тувинск/ (дата обращения: 10.01.2021).

${ }^{2}$ Оюн Д., Монгуш С. Ветераны тувинского кавалерийского эскадрона несут потери - умерла санинструктор Галина Тонмитовна Доваадор [Электронный ресурс] // ИА «Тува Онлайн». 23 февраля 2005. https://www. tuvaonline.ru/2005/02/23/dovaador.html (дата обращения: 10.01.2021).

3 Чалзырай Ц., Шимит Б. Фронтовичка Сыына Кыргыс, чемпионка, наездница ТНР [Электронный ресурс] // ИА «Тува Онлайн». 14 мая 2010. URL: https://www.tuvaonline.ru/2010/05/14/2849_tnr.html (дата обращения: 10.01.2021).

${ }^{4}$ Дулуш С. Ч. Я живу на улице Героя - Сарыглар Часкал [Электронный ресурс] // Проект для одаренных детей «Алые паруса». 2016, 22 июня. URL: https://nsportal.ru/ap/library/drugoe/2016/07/22/ya-zhivu-na-ulitse-geroyasaryglar-chaskal (дата обращения: 10.01.2021).
} 
Кызыл, чтобы стать постоянной корреспонденткой газет «Молодежь Тувы», «За коммунистический труд», «Тувинская правда». Родившаяся в 1933-м году в Москве, она явила своей биографией типику социального поведения советской молодежи, отправлявшейся в 1950-е покорять целину, строить новые города, создавать научные центры за Уральским хребтом... Именно в Туве расцвел поэтический дар С. Козловой; ее стихи стали переводиться на тувинский язык, а после смерти в 1997 г. вышел

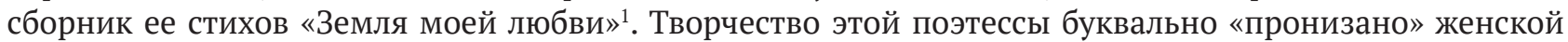
темой, центральными сюжетами были темы женского труда и женского героизма.

В сравнительном ключе стоит признать, что в топонимике городов республики отсутствуют названия улиц, связанные с женщинами - выдающимися революционерками. При этом в целом по России, в городах с дореволюционной историей, переживших в том числе и топонимическую революцию 1917-1922 гг. наличие таких улиц является характерной тенденцией (многочисленные улицы Клары Цеткин, Марии Ульяновой, Розы Люксембург, Инессы Арманд, Крупской и др.) (Забелин, 2006: 77). Но такое расхождение объясняется относительной молодостью административного устройства тувинской республики в составе российского государства.

Вклад женщин в социокультурное пространство городов Тувы опосредованно выразился в новых урбанонимах: парк Семейный, улица Детства, Площадь Учителя. Не случайна и улица Веры Кучун в крупном поселке городского типа Каа-Хем (в котором из 137 улиц -3 названы именами женщин). Вера Айжиевна Кучун работала учителем биологии, представительница известной в республике династии учителей, сама - потомственный учитель, воспитавшая и детей-учителей. И если наличие обезличенных улиц (т. н. учительских) в постсоветских городах достаточно распространенная традиция, то улицы, названные в честь конкретных выдающихся учителей (как мужчин, так и женщин), являются очень большой редкостью, и в этой связи пример тувинского поселка Каа-Хем уникален.

Также важно отметить наличие в Кызыле Площади Учителя и установленного здесь памятника с женщиной-учительницей в окружении детей-учеников. Подобный пример символического закрепления почета и уважения к этой профессии, а также всем учителям (преимущественно женщинам в советской и постсоветской традиции) имеет большое значение в формировании пространства исторической памяти.

В начале 2000-х гг. тувинский стрит-нейминг пополнился местами памяти, связанными с именем художницы Нади Рушевой (Найдан Николаевны Рушевой, 1952-1969). Хотя она родилась в Улан-Баторе в семье советского художника Н. К. Рушева (1918-1975), по матери, Н. Д. Ажикмаа-Рушевой (1926-2015), одной из первой тувинской балерины, она была теснейшим образом связана с тувинской культурной традицией. Имя талантливой художницы-графика в конце 1960-х гг. гремело по всему СССР, и еще при жизни ее матери было признано знаковым для социально-исторической памяти республики (Айжы, Бурбужеп, 2019: 60). Имя Нади Рушевой в 1997 г. было присвоено центральной детской школе искусств; одновременно на улице Ленина, д. 7 в Кызыле расположился музей ее имени (380 экспонатов были переданы этому музею матерью Нади). Музей Нади Рушевой существовал в качестве филиала при Тувинском краеведческом музее в 1993-2010 гг., а затем стал частью Национального музея республики Тыва (там же: 61). В четвертом по величине тувинском городе Чадан в 2000-е годы появилась и улица Нади Рушевой, закрепляя историческую память, связанную с молодой художницей и ее выдающейся мамой-тувинкой, а в Москве школа № 1466 (в которой она училась в старших классах) в Южном административном округе получила также право носить имя этой носительницы тувинской культуры ${ }^{2}$. Также в 2013-м году в день города Москвы около школы торжественно был открыт Народный парк имени Нади Рушевой. В парке установлена скульптура в память о Надежде, которую выполнил всемирно известный скульптор Андрей Волков. Он сумел воплотить в своем произведении два рисунка Нади «кентавренка» и ее автопортрет ${ }^{3}$.

Парадоксом является не многочисленность урбанонимов, связанных с Надей Рушевой в Республике Тыва, а непредставленность не менее значимых для ее истории женских имен других тувинских

\footnotetext{
${ }^{1}$ Куулар Н. «Мне песни петь - как воду пить...»: Светлане Владимировне Козловой - 85 лет [Электронный ресурс] // Тувинская правда. 1 марта 2018. URL: http://archive.tuvapravda.ru/content/mne-pesni-pet-kak-vodu-pit (дата обращения: 10.01.2021).

${ }^{2}$ Официальный сайт Государственного бюджетного общеобразовательного учреждения города Москвы «Школа № 1466 имени Надежды Рушевой»: https://sch1466u.mskobr.ru/ (дата обращения: 10.01.2021).

${ }^{3}$ Народный парк Надежды Рушевой [Электронный ресурс] // Москва - сегодня, будь в курсе! 2017, 23 августа. URL: http://moscowalk.ru/uao/caricyno/parki/park-rushevoi.html (дата обращения: 10.01.2021).
} 
деятельниц культуры, прежде всего писательниц - Екатерины Туктуг-ооловна Тановой (1930-1920) народной поэтессы Тувы, драматурга и переводчицы, писательницы Галины Дулушовны Маспыкоол (1957-2020), столь ярко описывавшей женскую долю; других известных женщин. Хотя они есть и их заслуги признаны. Так, в Туве есть официальный список «Заслуженных людей Тувы ХХ века», опубликованный в специальном издании местного правительства - «Государственная книга Республики Тыва» ${ }^{1}$. И включение в нее приравнивается к высшей государственной награде - ордену Республики Тыва². Из 264 упомянутых в списке лиц 30 - женщины.

При этом в топонимике ряда городов республики вообще нет женских имен. Из 55 улиц второго по величине города Тувы - Ак-Довурака (с численностью населения около 13 тысяч жителей в 2020 г.) не найдено ни одной улицы, названной женским именем. Из 73-х улиц третьего по величине города Тувы - Шагонара - также нет ни одной, названной в честь выдающихся женщин. Однако, важно отметить, что на карте города есть улица Чодураа (одно из самых распространенных женских имен в Туве, в переводе с тувинского - «Черемуха»). При этом масса улиц названа в честь деятелей России и Тувы: Х. Д. Очур (участника Великой Отечественной войны), генерала Сергея Шойгу (современного деятеля, министра обороны РФ), Кызыл Эник-Кудажи (заслуженного писателя Тувинской АССР), Сергея Пюрбю (народного писателя Тувы)... Ни одной «женской улицы» нет на карте Турана - самого маленького города Республики (5000 жителей в 2020 г.), в котором, однако есть в числе 57 улиц - 16, названных именами мужчин.

Поскольку Тува является ярко выраженной этнической республикой (более $80 \%$ населения - тувинцы), ее особенностью, в отличие от многих других российских регионов, не имеющих столь значительного перевеса числа коренного населения в общем составе населения, является закрепление в топонимике двух основных элементов социальной памяти - связанных с историко-культурным наследием тувинского народа, и связанных с наследием России в целом. В этой связи для тувинской топонимической модели более близкими являются модели других этнических республик: Башкортостана, Бурятии, Татарстана, Адыгеи и др. Однако, стоит отметить, что и в этих регионах женские имена выдающихся местных женщин - деятелей культуры, спорта, науки, образования и т. д. - также практически не представлены в пространстве региональной топонимики (см. например: Сальникова, 2004; Тугузбаева, 2011 и др.). Мужские же имена, напротив, составляют основу формирования средствами городской топонимики социальной памяти. Объяснить это можно с одной стороны влиянием общемировых практик (6\% «женских» улиц в Париже, 1,1\% - в Лионе, 0,6\% - в Марселе $)^{3}$, а с другой стороны и общероссийской топонимической традицией.

\section{Статистический анализ топонимики}

Итог исследования представлен в таблице: из общего числа улиц в городах и поселениях городского типа в Республике Тыва нашлось лишь 15 (с общим числом улиц 1325), в которых так или иначе запечатлена женская социальная память, что составляет всего 1\% в общем процессе стрит-нейминга. Это сопоставимо с долей улиц, связанных с досоветской (дореволюционной) историей, их около $3 \%$. В столице республики, Кызыле, из 919 улиц «женскими» являются всего 94. При этом львиная доля названий, как и во многих странах, связана с географическими наименованиями, и все же в общем числе тувинских городов доля «мужских» улиц составляет 14\% от общего числа, доля улиц, связанных с историческими событиями советского периода, $-18 \%$.

Таким образом, проанализировав топонимический социокультурный ландшафт городов и поселков городского типа Республики Тыва с целью ответить на вопрос о существовании гендерного баланса в процессе сохранения и популяризации женской социальной памяти, мы сделали вывод, что улиц, названных в честь женщин, как и в любой стране, много меньше, чем иных (например, 6\%

\footnotetext{
${ }^{1}$ Заслуженные люди Тувы XX века: Государственная книга республики Тыва / отв. ред. В. Я. Тимофеев, В. Ф. Чадамба. Кызыл: Тувинское книжное издательство, 2004. 260 с.

2 Закон Республики Тыва «О государственной книге Заслуженные люди Тувы XX века» // Заслуженные люди Тувы XX века: Государственная книга республики Тыва / отв. ред. В. Я. Тимофеев, В. Ф. Чадамба. Кызыл: Тувинское книжное издательство, 2004. 260 с. С. 7.

${ }^{3}$ The feminisation of street names: useful debate or a political artifice? [Электронный pecypc] // Into The Minds. 11.03. 2020. URL: https://www.intotheminds.com/blog/en/feminisation-street-names/ (дата обращения: 10.01.2021).

${ }^{4}$ Список улиц города Кызыл на сайте https://kladr-rf.ru/

${ }^{5}$ The feminisation of street names: useful debate or a political artifice? ...
} 
в Париже,27,5\% в Лондоне, от 4 до 12\% (по разным оценкам) в Милане) ${ }^{5}$. Это мировой тренд, хотя в странах ЕС и США в последнее время публикуются многочисленные статьи, указывающие на то, что малочисленность женских имен на карте городов мешает преемственности поколений, выхолащивает значимость историко-культурного наследия, создаваемого в том числе женщинами. Особую значимость проблеме (и ее особенности в российских условиях) придает социально-демографический кризис постсоветского периода, под ударом которого в первую очередь оказалось мужское население, теряющее значимость и удельный вес в старших возрастных группах (как раз в наибольшей степени включающих представителей управленческих должностей, интеллигенции, признанных заслуг в разных сферах, которые могут быть увековечены в социальной памяти путем городской топонимики). Подобный демографический дисбаланс среди старших возрастных групп подтверждается учеными на материалах статистических данных по Республике Тыва (Степанофф, 2009: 135).

Множество женских имен остается вне социокультурного пространства городов республики, хотя на ее карте остаются, например, в Кызыле: Безымянная улица, а также множество дублирующих названий: 11-я Линия, 2-я Заречная, 2-я Листвянка, 2-я Лесная и т. д. Ту же картину можно обнаружить при анализе списков названий улиц г. Москвы (из 3127 названий нашлось всего 40 урбанонимов, связанных с женщинами именами (Забелин, 2006); правда, автором не проанализированы причины этого сексистского дисбаланса). Меж тем, такое соотношение вполне сопоставимо с нашими подсчетами по Туве.

Аналогичная ситуация и в целом по России. Например, в Перми в названиях улиц фигурируют различные географические наименования. Много имён дала эпоха индустриализациии. Гораздо меньше лирики - разных Грушевых, Берёзовых и Белых. Улиц, названных в честь исторических личностей, примерно пятая часть. Из них «мужские» имена носят 250 улиц (цифра примерная - не всегда название можно соотнести с конкретным персонажем), а «женские»-только $15^{1}$.

\section{Заключение}

Подводя итоги проведенному исследованию названий улиц - обычных пространственных маркеров, которые (ориентируя в пространстве) вписывают те или иные имена, факты, события в пейзаж идеологического этоса и политических символов, - трудно не сделать вывод о маскулинизированности ведущего дискурса в стрит-нейминге Республики Тыва. Названия улиц в городах и поселениях Тувы это культурные арены борьбы за власть между ведущими дискурсами. Герои (чьи имена зафиксированы урбанонимами - памятниками, присвоенными именами клубов, школ, библиотек, вузов и т. д., но прежде всего названиями переулков, улиц, проспектов) из антропо-социологической перспективы видятся разделенными по этнической принадлежности, идеологической привязке и, конечно, полу. Никакого «механизма продвижения пространственной справедливости» (Alderman, Inwood, 2013: 212) в отношении двух полов в современном городском планировании Тувы не выработать без самого факта признания обнаруженного дисбаланса.

Люди вначале придают названиям улиц очевидно личное, контекстное значение (подтвержденное эмоциональным резонансом), но впоследствии уже реже задумываются о личностях, чьими именами названы их улицы. И все же в социальном контексте потребления культурных ценностей, в неосознанном освоении культурных богатств наречение улиц именами имеет огромное эдукологическое и воспитательное значение. Своим проектом мы ставим задачу обратить внимание на проблему дисбаланса в городской и сельской топонимике, на недостаточное признание женского вклада в историко-культурное наследие Тувы. При планировании нового социокультурного пространства городов Республики Тыва (строительство новых кварталов, планирование территорий под коттеджную, дачную, частную, промышленную застройку) данный перекос в нейминге легко устраним. Причины сохранения гендерного дисбаланса - в упущениях градостроительного законодательства (не требующего его соблюдения), в сложившихся гендерных стереотипах национальной культуры и традиционного (патриархального) гендерного контракта, что (как показали сравнения) характерно для многих городов в России, и в мире. Да, нет пока доказательств того, что прославление женского дела посредством топонимии в прямом смысле ускоряет женскую эмансипацию. Но все же названия улиц присутствуют в коллективном бессознательном, и пусть память об их происхождении со временем

\footnotetext{
${ }^{1}$ Инфографика: Неженское лицо пермской топонимики [Электронный ресурс] // Звезда. 2017, 8 мapта. URL:

https://zvzda.ru/infographics/c26141704293 (дата обращения: 10.01.2021).
} 
теряется, все же лейтмотивная культурная работа, нацеленная на сохранение женской социальной памяти о повседневном, о женском вкладе в культуру республики, может отчасти исправить дело.

Республика Тыва является частью Российской Федерации и находится в орбите культурно-исторического влияния России, поэтому и проблемы городской топонимики у них общие, актуализированные европейской интеллектуальной мыслью, озаботившейся сохраняющейся маскулинностью стритнейминга. Российское экспертное сообщество обращает внимание на то, что компактность локуса (Республика Тува) и своевременность артикуляции проблемы может помочь в скорейшем ее решении. Значимость ее - в необходимости учета гендерного фактора в трактовке национальной памяти, носителями которой станут следующие поколения граждан.

\section{СПИСОК ЛИТЕРАТУРЫ}

Айжы, Ж. Э., Бурбужеп, Д. Д. (2019) Графика Нади Рушевой в контексте экспозиционной деятельности Национального музея Тувы // Новые исследования Тувы. № 2. С. 59-71. DOI: 10.25178/nit.2019.2.5

Анайбан, 3. В. (2005) Женщины Тувы и Хакасии в период российских реформ. М. : Институт востоковедения PAH. 243 c.

Анжиганова, Л. В., Ак-Лама, С. М. (2016) Мир женщин современной Тувы [Электронный ресурс] // Новые исследования Тувы. № 2. С. 105-115. URL: https://nit.tuva.asia/nit/article/view/97 (дата обращения: 10.01.2021).

Анжиганова, Л. В., Тюльберова, А. М. (2019) Мир женщин кочевой культуры // Тенгрианство и эпическое наследие народов Евразии: истоки и современность : сб. статей VII Международной научно-практической конференции / отв. ред Л. В. Федорова. Якутск : Международный фонд исследования Тенгри. 360 с. С. 37-42.

Баранова, Е. В. (2011) Формирование городской социально-культурной среды и динамика топонимикона русского провинциального города в XVIII начале XX В. (на материале городов Тамбовской губернии) // Социальноэкономические явления и процессы. № 9. С. 169-173.

Вайнштейн, С. И. (1961) Тувинцы-тоджинцы. М. : Наука. 218 с.

Вайнштейн, С. И. (1994) Роль женщины в тувинских народных традициях (о свободе женщины у кочевников центра Азии) // Женщина и свобода: пути выбора в мире традиций и перемен. Мат-лы Межд. конф. 1993 г. / ред. В. А. Тишков и др. М. : Наука. 448 с. С. 411-416.

Волков, Г. Н., Салчак, К. Б., Шаалы, А. С. (2009) Этнопедагогика тувинского народа. Кызыл : Билиг. 212 с.

Горонова, Г. В. (2005) Феномен города в духовном мире человека. Омск : Омск. гос. пед. ун-т. 150 с.

Доржу, 3. Ю. (1993) Социальное положение женщин в Республике Тува. История и современность (1921-1993 гг.) : дисс.... д-ра ист. н. М. 421 с.

Жиленкова, И. И. (2012) Топонимы Белгородской области (системный лингвоанализ названий населенных пунктов). Белгород : ИД «Белгород». 124 с.

Забелин, Н. Ю. (2006) Женские имена московского топонимикона // Женщина в российском обществе. № 4. С. $76-79$.

Забелина, В. А. (1977а) Женщины освобожденной Тувы в борьбе за новую жизнь (1921-1944 гг.) // Великий Октябрь и проблемы новейшей истории / отв. ред. Ю. Л. Аранчын. Кызыл: ТНИИЯЛИ. 147 с. С. 90-104.

Забелина, В. А. (1977b) Раскрепощение женщины-тувинки и ее участие в некапиталистическом развитии Тувы (1921-1944 гг.) : автореф. дисс. ... канд. истор. наук. Новосибирск. 22 с.

Историческая экология и историческая демография (2003) : сб. научных статей / под ред. Ю. А. Полякова. М. : Росспэн. 383 с.

Карамзин, Н. М. (1803) Известие о Марфе-Посаднице // Вестник Европы. № IX (12). С. 294-302.

Мунзук, Т. Т. (1990) Прогрессивные идеи и опыт тувинской народной педагогики : автореф. ... канд. пед. н. Казань. 16 с.

Никитин, С. А. (2020) Страна имен. Как мы называем улицы, деревни и города в России. М. : НЛО. 320 с.

Полюшкевич, О. А., Попова, М. В. (2018) Влияние топонимики на идентичность жителей города (по материалам Иркутска) // Социодинамика. № 9. С. 86-97.

Преловская, С. Е., Пуляевская, Е. В. (2015) Исторический центр города: предложения по сохранению и развитию уличного пространства // Вестник Иркутского государственного технического университета. № 4. С. 123-130.

Пушкарева, Н. Л. (2019) Особенности памяти о женском социальном прошлом и труд историка // Вестник Российского университета дружбы народов. Серия: Исторические науки. Т. 18. № 2. С. 206-213.

Рыженко, В. Г. (2010) Образы и символы советского города в современных исследовательских опытах: региональный аспект. Омск : Изд-во ОмГУ. 340 с. 
Сальникова, А. А. (2004) Советская власть и культурный ландшафт провинциального города (Казань, 1920-30 гг.) // Россия и современный мир. № 1. С. 140-160.

Степанофф, Ш. (2009) Метаморфозы родства у тувинцев // Этнографическое обозрение. № 4. С. 129-145.

Субботин, С. В. (2016) Социальное положение женщины в традиционном обществе тувинцев: повседневность и исследовательские нарративы // Вестник Московского университета. Сер. 8. История. № 2. С. 109-120.

Сундуй, Г. Д. (2009) Мир детства кочевой Азии. Кызыл : Ин-т развития национальной школы. 168 с.

Тугузбаева, О. В. (2011) Имена собственные как номинация улиц г. Бирска Республики Башкортостан // Интеллектуальный потенциал XXI века: ступени познания. № 5-1. С. 97-100.

Alderman, D, Inwood, J. (2013) Street Naming and the Politics of Belonging: Spatial Injustices in the Toponymic Commemoration // Social \& Cultural Geography. Vol. 14(2). P. 211-233.

Azaryahu, M. (1996) The power of commemorative street names // Environment and planning D: Society and Space. № 14(3). P. 311-330.

Azaryahu, M. (2011) The Critical Turn and Beyond: The Case of Commemorative Street Naming [Электронный pecypc] // ACME: An International E-Journal for Critical Geographies. Vol. 10 (1). P. 28-33. https://www.acme-journal.org/ index.php/acme/article/view/883 (дата обращения: 10.01.2021).

Haldar, A. (2013) Women in Masculinized Memories: Narrating the Nation through Vocabularies of Discourse // Journal d'comparatius estudis: art, literature, pensament. Vol. 7. P. 41-56.

Rusu, M. S. (2020) Street Names through Sociological Lenses // Part 1. Social Change Review. Vol 18. DOI: https://doi. org/10.2478/scr-2020-0001

Дата поступления: 12.01.2021 2.

\section{REFERENCES}

Aizhy, Zh. E. and Burbuzhep, D. D. (2019) Grafika Nadi Rushevoi v kontekste ekspozitsionnoi deiatel'nosti Natsional'nogo muzeia Tuvy [Graphic art of Nadya Rusheva in the context of exhibition work at the National Museum of the Republic of Tuva]. New Research of Tuva, no. 2, pp. 59-71. (In Russ.). DOI: https://doi.org/10.25178/nit.2019.2.5

Anaiban, Z. V. (2005) Zhenshchiny Tuvy i Khakasii v period rossiiskikh reform [Women of Tuva and Khakassia in the period of reforms in Russia]. Moscow, Institut vostokovedeniia RAN. 243 p. (In Russ.).

Anzhiganova, L. V. and Ak-Lama, S. M. (2016) Mir zhenshchin sovremennoi Tuvy [Women's world in contemporary Tuva]. New Research of Tuva, no. 2, pp. 105-115 [online] Available at: https://nit.tuva.asia/nit/article/view/97 (access date: 10.01.2021). (In Russ.).

Anzhiganova, L. V. and Tiul'berova, A. M. (2019) Mir zhenshchin kochevoi kul'tury [The world of women of nomadic culture]. In: Tengrianstvo i epicheskoe nasledie narodov Evrazii: istoki i sovremennost' [Tengrianism and the epic heritage of the peoples of Eurasia: origins and modernity] : collection of papers presented at the $7^{\text {th }}$ International research conference / ed. by L. V. Fedorova. Yakutsk, Mezhdunarodnyi fond issledovaniia Tengri. 360 p. Pp. 37-42.

Baranova, E. V. (2011) Formirovanie gorodskoi sotsial'no-kul'turnoi sredy i dinamika toponimikona russkogo provintsial'nogo goroda v XVIII nachale XX V. (na materiale gorodov Tambovskoi gubernii) [Formation of the city welfare environment and dynamics of toponimikon of Russian country town from the 18 th to the start of the $20^{\text {th }}$ century: the case of towns in the Tambov province]. Social-economic phenomena and processes, no. 9, pp. 169-173. (In Russ.).

Vainshtein, S. I. (1961) Tuvintsy-todzhintsy. Istoriko-etnograficheskie ocherki [Tozhu Tuvans: historical and ethnographic essays]. Moscow, Nauka. 218 p. (In Russ.).

Vainshtein, S. I. (1994) Rol' zhenshchiny v tuvinskikh narodnykh traditsiiakh (o svobode zhenshchiny u kochevnikov tsentra Azii) [The role of women in Tuvan folk traditions: on the freedom of women among the nomads of Central Asia]. In: Zhenshchina i svoboda: puti ybora $v$ mire traditsii i peremen [Woman and freedom: making choice in the world of traditions and changes]. Mat-ly Mezhdunarod. konf. 1993 / ed. by V. A. Tishkov et al. Moscow, Nauka. 448 p. Pp. 411-416. (In Russ.).

Volkov G. N., Salchak K. B. and Shaaly A. S. (2009) Etnopedagogika tuvinskogo naroda [The ethnopedagogy of the Tuvan people]. Kyzyl, Tyvapoligraf. 212 p. (In Russ.).

Goronova, G. V. (2005) Fenomen goroda $v$ dukhovnom mire cheloveka [The phenomenon of the city in the spiritual world of man]. Omsk, Omsk. Gos. ped. Un-t. 150 p. (In Russ.).

Dorzhu, Z. Yu. (1993) Sotsial'noe polozhenie zhenshchin v Respublike Tuva. Istoriia i sovremennost' (1921-1993 gg.) [The social status of women in the Republic of Tuva. History and Modernity, 1921-1993]: Diss. ... Doctor of History Moscow. 421 p. (In Russ.).

Zhilenkova, I. I. (2012) Toponimy Belgorodskoi oblasti (sistemnyi lingvoanaliz nazvanii naselennykh punktov) [Toponyms of the Belgorod oblast’: a systemic linguistic analysis]. Belgorod, ID «Belgorod». 124 p. (In Russ.).

Zabelin, N. Yu. (2006) Zhenskie imena moskovskogo toponimikona [Female names of the Moscow toponymicon]. Zhenshchina $v$ rossiiskom obshchestve, no. 4, pp. 76-79. (In Russ.). 
Zabelina, V. A. (1977a) Zhenshchiny osvobozhdennoi Tuvy v bor'be za novuiu zhizn' (1921-1944 gg.) [Women of liberated Tuva in their struggle for a new life, 1921-1944]. In: Velikii Oktiabr' i problemy noveishei istorii Tuvy [Great October and problems of the modern history of Tuva] / ed. by Yu. L. Aranchyn. Kyzyl, Tuvan book publishing house. 147 p. Pp. 90-104. (In Russ.).

Zabelina, V. A. (1977b) Raskreposhchenie zhenshchiny-tuvinki $i$ ee uchastie v. nekapitalisticheskom razvitii Tuvy (1921-1944 gg.) [Emancipation of the Tuvan woman and her participation in the non-capitalist development of Tuva, 1921-1944] : Abstract of Diss.... Candidate of History. Novosibirsk. 22 p. (In Russ.).

Istoricheskaia ekologiia i istoricheskaia demografiia [Historical ecology and historical demography] (2003) : a collection articles / ed. by Yu. A. Poliakova. Moscow, Rosspen. 383 p. (In Russ.).

Karamzin, N. M. (1803) Izvestie o Marfe-Posadnitse [The News about Marfa Posadnitsa]. Vestnik Evropy, no. IX (12), pp. 294-302. (In Russ.).

Munzuk, T. T. (1990) Progressivnye idei i opyt tuvinskoi narodnoi pedagogiki [Progressive ideas and experience of Tuvan folk pedagogy]: Abstract of Diss. ... Candidate of Pedagogy. Kazan'. 16 p. (In Russ.).

Nikitin, S. A. (2020) Strana imen. Kak my nazyvaem ulitsy, derevni i goroda v Rossii [The land of names: What we call the streets, villages and cities in Russia]. Moscow, NLO. 320 p. (In Russ.).

Poliushkevich, O. A. and Popova, M. V. (2018) Vlianie toponimiki na identichnost' zhitelei goroda (po materialam Irkutska) [The influence of toponymy on the identity of city residents: the case of Irkutsk]. Sotsiodinamika, no. 9, pp. 86-97. (In Russ.).

Prelovskaia, S. E. and Puliaevskaia, E. V. (2015) Istoricheskii tsentr goroda: predlozheniia po sokhraneniiu i razvitiiu ulichnogo prostranstva [Historical city center: proposals on street space preservation and development]. Vestnik Irkutskogo gosudarstvennogo tekhnicheskogo universiteta, no. 4, pp. 123-130. (In Russ.).

Pushkareva, N. L. (2019) Osobennosti pamiati o zhenskom sotsial'nom proshlom i trud istorika [Features of memory of female social past and labor of historian]. Vestnik Rossiiskogo universiteta druzhby narodov. Issue: Istoricheskie nauki, vol. 18, no. 2, pp. 206-213. (In Russ.).

Ryzhenko, V. G. (2010) Obrazy i simvoly sovetskogo goroda v sovremennykh issledovatel'skikh opytakh: regional'nyi aspekt [Images and symbols of the Soviet city in modern research experiments: a regional aspect]. Omsk, Izd-vo OmGU. 340 p. (In Russ.).

Sal'nikova, A. A. (2004) Sovetskaia vlast' i kul'turnyi landshaft provintsial'nogo goroda (Kazan', 1920-30 gg.) [The Soviet authorities and cultural landscape of a provincial city: Kazan in the 1920-1930s]. Rossiia i sovremennyi mir, no. 1, pp. 140-160. (In Russ.).

Stepanoff, Sh. (2009) Metamorfozy rodstva u tuvintsev [Metamorphoses of kinship among the Tuvans]. Etnograficheskoe obozrenie, no. 4, pp. 129-145. (In Russ.).

Subbotin, S. V. (2016) Sotsial'noe polozhenie zhenshchiny v traditsionnom obshchestve tuvintsev: povsednevnost' $\mathrm{i}$ issledovatel'skie narrativy [The social position of women in the traditional society of Tuva: everyday life and research narratives]. Vestnik Moskovskogo universiteta, issue 8. History, no. 2, pp. 109-120. (In Russ.).

Sundui, G. D. (2009) Mir detstva kochevoi Azii: opyt dukhovno-nravstvennogo vospitaniia [The world of childhood in nomadic Asia: the experience of spiritual and moral education]. Kyzyl, IRNSh. 168 p. (In Russ.)

Tuguzbaeva, O. V. (2011) Imena sobstvennye kak nominatsiia ulits g. Birska Respubliki Bashkortostan [Personal names in the nomination of streets in the town of Birsk, Republic of Bashkortostan]. Intellektual'nyi potentsial XXI veka: stupeni poznaniia, no. 5-1, pp. 97-100. (In Russ.).

Alderman, D. and Inwood, J. (2013) Street Naming and the Politics of Belonging: Spatial Injustices in the Toponymic Commemoration. Social \& Cultural Geography, vol. 14(2), pp. 211-233.

Azaryahu, M. (1996) The power of commemorative street names. Environment and planning D: Society and Space, no. 14(3), pp. 311-330.

Azaryahu, M. (2011) The Critical Turn and Beyond: The Case of Commemorative Street Naming. ACME: An International E-Journal for Critical Geographies, vol. 10 (1), pp. 28-33 [online] Available at: https://www.acme-journal.org/index.php/ acme/article/view/883 (access date: 10.01.2021).

Haldar, A. (2013) Women in Masculinized Memories: Narrating the Nation through Vocabularies of Discourse. Journal d'comparatius estudis: art, literature, pensament, vol. 7, pp. 41-56.

Rusu, M. S. (2020) Street Names through Sociological Lenses. Part 1. Social Change Review, vol. 18. DOI: https://doi. org/10.2478/scr-2020-0001

Submission date: 12.01.2021. 